\title{
Impact of Organic Nutrient Management Practices on Yield Attributes and Yield of Summer Mungbean
}

\author{
Sharvan Kumar Yadav ${ }^{1}$, H. B. Babalad², S. K. Sharma ${ }^{1}$, R. S. Choudhary ${ }^{1 *}$ and Naresh Kumar ${ }^{1}$ \\ ${ }^{1}$ Dept. of Agronomy, Maharana Pratap University of Agriculture \& Technology, Udaipur, Rajasthan (313 001), India \\ ${ }^{2}$ Dept. of Agronomy, University of Agricultural Sciences, Dharwad, Karnataka (510 008), India
}

\section{Article History}

Manuscript No. AR1648

Received in $5^{\text {th }}$ August, 2016

Received in revised form $4^{\text {th }}$ October, 2016

Accepted in final form $7^{\text {th }}$ October, 2016

\section{Correspondence to}

"E-mail: agroudr2013@gmail.com

\section{Keywords}

Mungbean, panchagavya, vermicompost, FYM, vermiwash, PGPR, urea, yield

\begin{abstract}
Field experiment was conducted on summer mungbean under organic nutrient management at Main Agriculture Research Station (MARS), University of Agriculture Sciences, Dharwad, Karnataka, India during summer season of 2012-2013. The experiment comprise of eighteen treatment combinations with three main plot treatments of organic manures and six sub plot of liquid organic manures. Results revealed that application of EC (1/3)+VC (1/3)+GLM (1/3) equivalent to $50 \mathrm{~kg} \mathrm{P}_{2} \mathrm{O}_{5}$ with $5 \mathrm{t} \mathrm{FYM} \mathrm{ha}{ }^{-1}$ recorded significantly higher yield attributing characters like pod length, number of pods plant ${ }^{-1}$, seed weight plant $^{-1}$ and 1000 seed weight $(9.65 \mathrm{~cm}$, $18.86,6.85 \mathrm{~g}$ and $49.64 \mathrm{~g}$, respectively) as compared to organics alone equivalent RDP and was on par with RDF+FYM. Among liquid organic manures foliar application of panchagavya 5\% recorded significantly higher yield attributing characters as compared to other liquid organic manures but was on par with vermiwash $10 \%$ and cow urine @ $10 \%$. Significantly higher seed yield of mungbean was recorded with application of $\mathrm{EC}(1 / 3)+\mathrm{VC}(1 / 3)+\mathrm{GLM}(1 / 3)$ equivalent $50 \mathrm{~kg} \mathrm{P}_{2} \mathrm{O}_{5}$ with $5 \mathrm{t} \mathrm{FYM} \mathrm{ha}^{-1}\left(1368 \mathrm{~kg} \mathrm{ha}^{-1}\right)$ as compared to $(1 / 3)+\mathrm{VC}(1 / 3)+\mathrm{GLM}(1 / 3)$ equivalent $50 \mathrm{~kg} \mathrm{P}_{2} \mathrm{O}_{5}$ alone $\left(1258 \mathrm{~kg} \mathrm{ha}^{-1}\right)$ and was on par with RDF+FYM (1301 $\left.\mathrm{kg} \mathrm{ha}^{-1}\right)$. Among liquid organic manures, foliar application of panchagavya $5 \%$ recorded significantly higher grain yield ha-1 $(1430 \mathrm{~kg}$ $\mathrm{ha}^{-1}$ ) as compared to rest of the treatments except vermiwash $10 \%$ which was on par.
\end{abstract}

\section{Introduction}

India is the World largest producer, importer and consumer of pulses. For a country that faces persistent protein inflation and has preference for vegetarian diet, pulses are the most economical source of vegetable protein. Higher consumption of pulses will help to address the courage of pervasive malnutrition caused by protein deficiency among large section of Indian population. Low yields of pulses in India are due to non-availability of quality seed of improved varieties, cultivation under marginal and sub marginal soils under moisture stress, poor pest and disease management and unscientific post harvest management. Hence, there is an ample scope to improve the productivity of pulses through enhancing soil fertility and its productivity by improving soil organic carbon, soil moisture storage capacity and adopting integrated nutrient and pest management practices. The contribution of nutrients by organic amendments had traditionally been considered to be the best to increase the crop yield. Farmyard manure increased the productivity by maintaining the soil health with concomitant nutrient balance, besides minimizing the pollution hazards as well as fertilizer cost (Gayathri and Anburani, 2008). Sivakumar (2014) has mentioned that increasing concern for environmental safety and global demand for pesticide residue free food has evoked keen interest in crop production using eco-friendly products which are easily biodegradable and do not leave any harmful toxic residues besides conserving nature.

Recently organic farming has been recognized as alternative to conventional system for optimum utilization of all natural resources to get higher profitability. The crop productivity under organic production system can be enhanced through integrated organic nutrition by using different sources of nutrients which have different nutrient release pattern and efficiency. Combined application of organic manures mainly compost, vermicompost and gliricidia Green Leaf Manure (GLM) produced higher yield apart from improving soil health (Babalad et al., 2009). Further, the liquid organic manures meet the nutrient requirement of crops with greater nutrient 
use efficiency and also correct the deficiency of nutrients as and when noticed under organic production system (Shwetha, 2009). Vallimayil and Sekar (2012) reported to Panchagavya is an organic product blended from five different cow products, commonly applied to crop plants in organic farming. It is used as foliar spray, soil application and seed treatment. It can act as growth promoter and immunity booster.

Mungbean being a legume crop derives its greater nitrogen requirement through biological nitrogen fixation, which can be harnessed by providing good physical and chemical condition of soil. The edhaphic environment under organic production system more congenial for good crop growth and application of organics regularly maintains it at optimum level. Studies have shown that the legume crop productivity can be enhanced and sustained under organic production system. Indiscriminate and continuous use of chemical fertilizers has also shown adverse effect on soil physical, chemical and biological properties there by affecting the sustainability of crop production, besides causing environmental pollution (Virmani, 1994). Keeping in mind these facts present study was done to assess the impact of organic nutrient management practices on yield attributes and yield of summer mungbean.

\section{Materials and Methods}

Field experiment was conducted during summer season of 2012-13 in a cropping system soybean-wheat-green gram (summer). The experiment was carried out at MARS, Dharwad by using split plot design. Gross size of each plot was $4.8 \times 3.0 \mathrm{~m}^{2}$. During the period of experimentation mean maximum temperature varied from $26.7^{\circ} \mathrm{C}$ to $36.9^{\circ} \mathrm{C}$ and minimum temperature varied from $13.2{ }^{\circ} \mathrm{C}$ to $21.8^{\circ} \mathrm{C}$.

The experiment comprise of eighteen treatment combinations with three main plot treatments of organic manures mainly $\mathrm{M}_{1}$ : Enriched compost (1/3)+vermicompost (1/3)+Glyceridia green leaf manure $(1 / 3)$ equivalent $50 \mathrm{~kg} \mathrm{P}_{2} \mathrm{O}_{5}, \mathrm{M}_{2}$ : EC $(1 / 3)+\mathrm{VC}(1 / 3)$ GLM (1/3) equivalent $50 \mathrm{~kg} \mathrm{P}_{2} \mathrm{O}_{5}$ with $5 \mathrm{t}$ FYM and $\mathrm{M}_{3}$ : RDF+FYM $5 \mathrm{tha}^{-1}$ and six sub plot of liquid organic manures mainly, $\mathrm{L}_{1}$ : Cow urine $10 \%$ two sprays at flowering and $15 \mathrm{DAF}, \mathrm{L}_{2}$ : Panchagavya $5 \%$ two sprays at flowering and $15 \mathrm{DAF}, \mathrm{L}_{3}$ : Vermiwash $10 \%$ two sprays at flowering and $15 \mathrm{DAF}_{4}$ : $\mathrm{PGPR}$ two sprays at flowering and $15 \mathrm{DAF}, \mathrm{L}_{5}$ : Urea $2 \%$ two sprays at flowering and $15 \mathrm{DAF}$ and $\mathrm{L}_{6}$ : Control (water spray).

The soil of experimental was well drained, red sandy loam in texture having maximum water holding capacity $52 \%$ and bulk density $1.20 \mathrm{Mg} \mathrm{m}^{-3}$. Initial soil fertility status was moderately high in available nitrogen (191.2 $\left.\mathrm{kg} \mathrm{ha}^{-1}\right)$ and phosphorus (20.36 kg ha-1) and high in available potassium $\left(283 \mathrm{~kg} \mathrm{ha}^{-1}\right)$. At the time of sowing, $100 \%$ of recommended dose of nitrogen and phosphorus (25:50 N: $\mathrm{P}_{2} \mathrm{O}_{5}: \mathrm{kg}$ ha$\left.{ }^{1}\right)+F Y M$ were applied to $\mathrm{M}_{3}$ treatment. GLM (fresh weight basis), FYM, enriched compost and vermicompost all were applied as treatments $\mathrm{s}^{-1} 10$ days before sowing. Panchagavya $5 \%$, vermiwash $10 \%$, cow urine $10 \%$, PGPR and urea $2 \%$ were applied as the treatments ${ }^{-1}$ at flowering and $15 \mathrm{DAF}$. Observations on yield attributing characters and yield were recorded at harvest.

\section{Results and Discussion}

\subsection{Yield attributes}

Results showed that (Table 1) combined application of organic manures with EC (1/3)+VC (1/3)+GLM (1/3) equivalent to recommended dose of $50 \mathrm{~kg} \mathrm{P}_{2} \mathrm{O}_{5}+5 \mathrm{t}$ FYM ha ${ }^{-1}$ recorded significantly higher pod length $(\mathrm{cm})$, number of pods plant ${ }^{-1}$ and test weight $(\mathrm{g})(10.43,18.86$ and 49.64 , respectively) as compared to organics EC $(1 / 3)+\mathrm{VC}(1 / 3)+\mathrm{GLM}(1 / 3)$ equivalent to recommended dose of $50 \mathrm{~kg} \mathrm{P}_{2} \mathrm{O}_{5}$ alone and was on par with RDF+5 t FYM ha ${ }^{-1}(9.82,18.21$ and 49.18 $\mathrm{g}$, respectively). Among liquid organic manures application of panchagavya $5 \%$ recorded significantly higher pod length $(\mathrm{cm})$, number of pods plant ${ }^{-1}$ and test weight $(\mathrm{g})(10.56$, 20.22 and 51.31, respectively) as compared to rest of the treatments except vermiwash $10 \%$ and cow urine $10 \%$. Significant improvement in number of pods could be due to increase in number of secondary branches, which might have resulted in development of more number of reproductive parts and the increase in sink size. Among liquid organic manures, foliar application of panchagavya $5 \%$ recorded significantly higher number of pods plant ${ }^{-1}$ (20.22 pods plant $^{-1}$ ) over rest of the treatments. The next best treatment was vermiwash $10 \%$ which was significantly superior over other treatments and was on par with cow urine $10 \%$. Similar results were obtained by Nekar et al. (2009) in groundnut and Yadav and Vijayakumari (2003) in chilli. Similar observations were also made in chickpea by Somasundaram et al. (2003) 3\% panchagavya was the ideal concentration for foliar spray on mungbean variety CO-4. They also stated that foliar application of panchagavya at the rate of $3 \%$ at $15,25,40$ and 50 DAS with no inorganic was the effective low cost technology in terms of grain yield of mungbean. Similarly, Kumaravelu and Kadambian (2009) observed that Panchagavya spray (3\%) at 10 DAS significantly increased the growth of greengram plants. Patil et al. (2012) reported that soil application of organic manures and foliar spray of liquid organic manures at flower initiation and 15 days after flowering (DAF) significantly enhanced the growth and yield parameters of chickpea viz., plant height, number of branches, leaf area index, total dry matter, number of root nodule and dry weight of nodules, number of pods plant ${ }^{-1}$. 


\begin{tabular}{|c|c|c|c|c|c|c|c|c|c|c|c|c|}
\hline \multirow[t]{2}{*}{$\begin{array}{l}\text { Liquid organic } \\
\text { manures (L) }\end{array}$} & \multicolumn{4}{|c|}{ Pod length $(\mathrm{cm})$} & \multicolumn{4}{|c|}{$\begin{array}{l}\text { Number of pods plant }{ }^{-1} \\
\text { organic manurial treatments }(\mathrm{M})\end{array}$} & \multicolumn{4}{|c|}{ Test weight (g) } \\
\hline & $\mathrm{M}_{1}$ & $\mathrm{M}_{2}$ & $\mathrm{M}_{3}$ & Mean & $\mathrm{M}_{1}$ & $\mathrm{M}_{2}$ & $\mathrm{M}_{3}$ & Mean & $\mathrm{M}_{1}$ & $\mathrm{M}_{2}$ & $\mathrm{M}_{3}$ & Mean \\
\hline $\mathrm{L}_{1}$ & 8.77 & 10.62 & 9.95 & 9.78 & 17.08 & 20.00 & 18.25 & 18.44 & 49.90 & 50.19 & 49.76 & 49.95 \\
\hline $\mathrm{L}_{2}$ & 9.75 & 11.28 & 10.64 & 10.56 & 18.83 & 21.92 & 19.92 & 20.22 & 50.66 & 51.67 & 51.60 & 51.31 \\
\hline $\mathrm{L}_{3}$ & 9.37 & 10.88 & 10.13 & 10.13 & 18.08 & 19.58 & 19.17 & 18.94 & 49.18 & 51.04 & 49.93 & 50.05 \\
\hline $\mathrm{L}_{4}$ & 8.55 & 10.00 & 9.58 & 9.38 & 15.17 & 18.08 & 18.75 & 17.33 & 46.66 & 48.07 & 49.16 & 47.97 \\
\hline $\mathrm{L}_{5}$ & 8.95 & 10.40 & 9.58 & 9.64 & 16.92 & 17.83 & 17.92 & 17.56 & 46.00 & 49.56 & 47.59 & 47.72 \\
\hline $\mathrm{L}_{6}$ & 8.02 & 9.40 & 9.05 & 8.82 & 15.83 & 15.75 & 15.25 & 15.61 & 45.43 & 47.29 & 47.02 & 46.58 \\
\hline Mean & 8.90 & 10.43 & 9.82 & & 16.99 & 18.86 & 18.21 & & 47.97 & 49.64 & 49.18 & \\
\hline For comparison & \multicolumn{2}{|c|}{$\mathrm{SEm} \pm$} & \multicolumn{2}{|c|}{$\operatorname{LSD}(p=0.05)$} & \multicolumn{2}{|c|}{$\mathrm{SEm} \pm$} & \multicolumn{2}{|c|}{$\operatorname{LSD}(p=0.05)$} & \multicolumn{2}{|c|}{$\mathrm{SEm} \pm$} & \multicolumn{2}{|c|}{$\operatorname{LSD}(p=0.05)$} \\
\hline $\mathrm{M}$ & \multicolumn{2}{|c|}{0.22} & \multicolumn{2}{|c|}{0.87} & \multicolumn{2}{|c|}{0.43} & \multicolumn{2}{|c|}{1.67} & \multicolumn{2}{|c|}{0.11} & \multicolumn{2}{|c|}{0.43} \\
\hline $\mathrm{L}$ & \multicolumn{2}{|c|}{0.21} & \multicolumn{2}{|c|}{0.62} & \multicolumn{2}{|c|}{0.35} & \multicolumn{2}{|c|}{1.02} & \multicolumn{2}{|c|}{0.13} & \multicolumn{2}{|c|}{0.38} \\
\hline Interaction $(\mathrm{M} \times \mathrm{L})$ & \multicolumn{2}{|c|}{0.71} & \multicolumn{2}{|c|}{ NS } & \multicolumn{2}{|c|}{0.98} & \multicolumn{2}{|c|}{ NS } & \multicolumn{2}{|c|}{0.44} & \multicolumn{2}{|c|}{ NS } \\
\hline
\end{tabular}

$\mathrm{L}_{1}$ : Cow urine $10 \%$ two sprays at flowering and $15 \mathrm{DAF} ; \mathrm{L}_{2}$ : Panchagavya $5 \%$ two sprays at flowering and $15 \mathrm{DAF} ; \mathrm{L}_{3}$ : Vermiwash $10 \%$ two sprays at flowering and $15 \mathrm{DAF} ; \mathrm{L}_{4}$ : PGPR two sprays at flowering and $15 \mathrm{DAF} ; \mathrm{L}_{5}$ : Urea $2 \%$ two sprays at flowering and $15 \mathrm{DAF} ; \mathrm{L}_{6}$ : Control (Water spray)

\subsection{Seed weight plant ${ }^{-1}\left(\right.$ plant $\left.^{-1}\right)$}

Result revealed that (Table 2) application of EC (1/3)+VC $(1 / 3)+$ GLM (1/3) equivalent recommended dose of $50 \mathrm{~kg}$ $\mathrm{P}_{2} \mathrm{O}_{5}$ with 5 t FYM ha ${ }^{-1}$ recorded significantly higher seed weight $\left(\mathrm{g} \mathrm{plant}^{-1}\right)$ and number of seed pod $^{-1}(6.85$ and 11.66) as compared to $\mathrm{EC}(1 / 3)+\mathrm{VC}(1 / 3)+\mathrm{GLM}(1 / 3)$ equivalent recommended dose of $50 \mathrm{~kg} \mathrm{P}_{2} \mathrm{O}_{5}$ alone (5.98 and 10.06) and was on par with RDF+FYM (6.40 and 11.06). Among liquid organic manures, foliar application of panchagavya $5 \%$ recorded significantly higher seed weight plant $^{-1}(7.15$ $\mathrm{g}$ plant $\left.^{-1}\right)$ and number of seed pod $^{-1}(11.96)$ as compared to rest of the treatments except vermiwash $10 \%$ which was on par. Patil et al. (2012) reported that soil application of organic manures and foliar spray of liquid organic manures at flower

Table 2: Effect of organic nutrient management practices on seed weight plant ${ }^{-1}$, number of seeds pod $^{-1}$ and grain yield of summer mungbean

\begin{tabular}{|c|c|c|c|c|c|c|c|c|c|c|c|c|}
\hline \multirow[t]{2}{*}{$\begin{array}{l}\text { Liquid organic } \\
\text { manures (L) }\end{array}$} & \multicolumn{4}{|c|}{ Seed weight plant ${ }^{-1}(\mathrm{~g})$} & \multicolumn{4}{|c|}{$\begin{array}{l}\text { Number of seeds pod } \\
\text { organic manurial treatments (M) }\end{array}$} & \multicolumn{4}{|c|}{ Grain yield $\left(\mathrm{kg} \mathrm{ha}^{-1}\right)$} \\
\hline & $\mathrm{M}_{1}$ & $\mathrm{M}_{2}$ & $\mathrm{M}_{3}$ & Mean & $\mathrm{M}_{1}$ & $\mathrm{M}_{2}$ & $\mathrm{M}_{3}$ & Mean & $\mathrm{M}_{1}$ & $\mathrm{M}_{2}$ & $\mathrm{M}_{3}$ & Mean \\
\hline $\mathrm{L}_{1}$ & 6.42 & 7.18 & 6.84 & 6.81 & 10.17 & 12.02 & 11.35 & 11.18 & 1284 & 1434 & 1367 & 1362 \\
\hline $\mathrm{L}_{2}$ & 6.71 & 7.70 & 7.05 & 7.15 & 11.15 & 12.68 & 12.04 & 11.96 & 1342 & 1538 & 1409 & 1430 \\
\hline $\mathrm{L}_{3}$ & 6.54 & 7.31 & 6.90 & 6.92 & 10.77 & 12.28 & 11.53 & 11.53 & 1307 & 1462 & 1379 & 1383 \\
\hline $\mathrm{L}_{4}$ & 5.27 & 6.31 & 5.82 & 5.80 & 9.62 & 11.07 & 10.65 & 10.44 & 1230 & 1261 & 1237 & 1243 \\
\hline $\mathrm{L}_{5}$ & 5.74 & 6.77 & 6.33 & 6.28 & 10.25 & 11.47 & 10.65 & 10.79 & 1250 & 1353 & 1265 & 1290 \\
\hline $\mathrm{L}_{6}$ & 5.17 & 5.81 & 5.44 & 5.47 & 8.42 & 10.47 & 10.12 & 9.67 & 1134 & 1161 & 1147 & 1147 \\
\hline Mean & 5.98 & 6.85 & 6.40 & & 10.06 & 11.66 & 11.06 & & 1258 & 1368 & 1301 & \\
\hline For comparison & \multicolumn{2}{|c|}{$\mathrm{SEm} \pm$} & \multicolumn{2}{|c|}{$\operatorname{LSD}(p=0.05)$} & \multicolumn{2}{|c|}{$\mathrm{SEm} \pm$} & \multicolumn{2}{|c|}{$\operatorname{LSD}(p=0.05)$} & \multicolumn{2}{|c|}{$\mathrm{SEm} \pm$} & \multicolumn{2}{|c|}{$\operatorname{LSD}(p=0.05)$} \\
\hline M & \multicolumn{2}{|c|}{0.11} & \multicolumn{2}{|c|}{0.43} & \multicolumn{2}{|c|}{0.16} & \multicolumn{2}{|c|}{0.64} & \multicolumn{2}{|c|}{19.74} & \multicolumn{2}{|c|}{77.51} \\
\hline $\mathrm{L}$ & \multicolumn{2}{|c|}{0.13} & \multicolumn{2}{|c|}{0.38} & \multicolumn{2}{|c|}{0.19} & \multicolumn{2}{|c|}{0.55} & \multicolumn{2}{|c|}{20.71} & \multicolumn{2}{|c|}{59.80} \\
\hline Interaction $(\mathrm{M} \times \mathrm{L})$ & \multicolumn{2}{|c|}{0.44} & \multicolumn{2}{|c|}{ NS } & \multicolumn{2}{|c|}{0.50} & \multicolumn{2}{|c|}{ NS } & \multicolumn{2}{|c|}{5.45} & \multicolumn{2}{|c|}{ NS } \\
\hline
\end{tabular}

$\mathrm{L}_{1}$ : Cow urine $10 \%$ two sprays at flowering and $15 \mathrm{DAF} ; \mathrm{L}_{2}$ : Panchagavya $5 \%$ two sprays at flowering and $15 \mathrm{DAF} ; \mathrm{L}_{3}$ : Vermiwash $10 \%$ two sprays at flowering and $15 \mathrm{DAF} ; \mathrm{L}_{4}$ : PGPR two sprays at flowering and $15 \mathrm{DAF} ; \mathrm{L}_{5}$ : Urea $2 \%$ two sprays at flowering and $15 \mathrm{DAF} ; \mathrm{L}_{6}$ : Control (Water spray) 
initiation and 15 days after flowering (DAF) significantly enhanced the 100-seed weight.

\subsection{Grain yield}

Results indicated that (Table 2) among organic manurial treatments, application of EC (1/3)+VC (1/3)+GLM (1/3) equivalent recommended dose of $50 \mathrm{~kg} \mathrm{P}_{2} \mathrm{O}_{5}$ with $5 \mathrm{t}$ FYM $\mathrm{ha}^{-1}$ recorded significantly higher seed yield (1368 $\left.\mathrm{kg} \mathrm{ha}^{-1}\right)$ as compared to $\mathrm{EC}(1 / 3)+\mathrm{VC}(1 / 3)+\mathrm{GLM}(1 / 3)$ equivalent to $\mathrm{P}_{2} \mathrm{O}_{5}$ alone $\left(1258 \mathrm{~kg} \mathrm{ha}^{-1}\right)$ and was on par with $\mathrm{RDF}+\mathrm{FYM}$ treatment $\left(1301 \mathrm{~kg} \mathrm{ha}^{-1}\right)$. Among liquid organic manures, foliar application of panchagavya $5 \%$ recorded significantly higher seed yield ha-1 $\left(1430 \mathrm{~kg} \mathrm{ha}^{-1}\right)$ as compared to rest of the treatments except vermiwash $10 \%$ which was on par. Significantly lower yield ha $\mathrm{h}^{-1}$ was recorded with control (water spray) treatment (1147 kg ha-1). The interactions of organic manures and liquid organic manures were nonsignificant. The cow dung in FYM and panchagavya act as a medium for the growth of beneficial microbes and cow urine provides nitrogen which is essential for crop growth upon fermentation with other ingredients in panchagavya has proved beneficial effect on growth, yield attributes and yield of crops (De Britto and Girija, 2006). Patil et al. (2012) reported that soil application of organic manures and foliar spray of liquid organic manures at flower initiation and 15 days after flowering (DAF) significantly enhanced the grain yield and haulm yield.

\section{Conclusion}

Higher yield of summer mungbean under organic management was found best with the application of EC $(1 / 3)+\mathrm{VC}$ $(1 / 3)+$ GLM (1/3) equivalent to recommended dose $50 \mathrm{~kg}$ $\mathrm{P}_{2} \mathrm{O}_{5}$ with 5 t FYM ha ${ }^{-1}$ along with liquid organic manure and panchagavya $5 \%$ foliar spray.

\section{References}

Babalad, H.B., Kambale, A.S., Bhat, S.N., Patil, R.K., Math, K.K., Shivanalli, G., Palakshappa, M.G., 2009. Sustainable groundnut production through organic approach. Journal of Oilseeds Research 26, 365-367.

De Britto, J.A., Girija, S.L., 2006. Investigation on the effect of organic and inorganic farming methods on blackgram and greengram. Indian Journal of Agricultural Research 40(3), 204-207.

Gayathiri, M., Anburani. A., 2008. Influence of soil and foliar application of organic and inorganic fertilizers on growth in kacholam (Kaempferia galanga L.). Advances in Plant Sciences 21, 475-477.

Kumaravelu, G., Kadambian, D., 2009. Panchagavya and its effect on the growth of the greengram cultivar K-851. International Journal of Plant Sciences 4(2), 409-414.

Nekar, N.M., Babalad, H.B., Bhat, S.N., Sreenivasa, M. N., 2009. Response of groundnut (Arachis hypogaea L.) to foliar application of liquid organic manures. Journal of Oilseeds Research 26(Sp. Issue), 390-392.

Patil, S.V., Halikatti, S.I., Hiremath, S.M., Babalad, H.B., Sreenivasa, M.N., Hebsur, N.S., Somanagouda, G., 2012. Effect of organics on growth and yield of chickpea (Cicer arietinum L.) in vertisols. Karnataka Journal of Agricultural Sciences 25(3), 326-331.

Sivakumar, T., 2014. Review on Panchagavya. International Journal of Advanced Research in Biological Sciences 1(8), 130-154.

Shwetha, B.N., Babalad, H.B., Patil, R.K., 2009. Effect of combined use of organics in soybean-wheat cropping system. Journal of Soil and Crops 19(1), 8-13.

Somasundaram, E.N., Meena, S.S., Thiyagarajan, K.K.C., Panneerselvam, S., 2003. Response of greengram to varied concentrations of Panchakavya (organic nutrition) foliar application. Madras Agricultural Journal 90(1-3), 169-172.

Vallimayil. J., Sekar, R., 2012. Investigation on the effect of panchagavya on Sounthern sunnhemp mosaic virus (SSMV) infected plant systems. Global Journal of Environmental Research 6(2), 75-79.

Virmani, S.M., 1994. The twenty first-Dr. R.V. Tamhane memorial Lecture: UNCEED Agenda 21: The new challenge for soil research. Journal of Indian Society of Soil Science 42, 516-523.

Yadav, H., Vijayakumari, B., 2003. Influence of vermicompost with organic and inorganic manures on biometric and yield parameters of chilli (Capsicum annuum L.). Crop Research 25(2), 236-243. 